\title{
Botanical Evaluation of Some Stevia (Stevia rebaudiana, Bertoni) Varieties under Different Nitrogen fertilizer Levels.
}

\author{
A. A. Tantawy*;A. E. Attia **; Nareyman. N. Kenawy **. \\ Agronomy Dep. Fac. of Agric., Minia University*Agricultural Research Center, Giza, Egypt. ** \\ Correspondence author: nareyman33@Gmail.Com
}

\begin{abstract}
Two field experiments were carried out at agricultural research center Giza Egypt. During 2015/2016 and 2016/2017 seasons to study the effect of nitrogen fertilizer levels (20,30 and $40 \mathrm{~kg} \mathrm{~N} / \mathrm{fed} / \mathrm{cut}$.) on some stevia varieties (china1, Egy1, spanti and shou2) growth characters in both seasons. The highest nitrogen rate of $40 \mathrm{~kg}$. $\mathrm{N} /$ fed /cut was significant in all studied growth and yield characters and gave the highest values as compared with the other two nitrogen treatments in both seasons.

stevia varieties were significantly different in all studied growth and yield characters. Egy1 varieties gave the highest values of all studied growth and yield characters except for Plant height and number of branches per plant where spanti cultivar gave the highest values in the first and second seasons.

Concerning the effect of the interaction between nitrogen fertilizer levels and stevia varieties on growth character values, nitrogen fertilizer level of $40 \mathrm{~kg} \mathrm{~N} / \mathrm{fed} / \mathrm{cut}$ applied to Egy1 varietie gave the highest values in all the three cuts studied except those of plant height and number of branches in both seasons.
\end{abstract}

Key words: stevia, nitrogen fertilizer, varieties.

\section{Introduction}

Stevia has zero calorie natural sweetener to substitute sugar form ingredients in the food habits of human being. leaves of stevia plant is heat and $\mathrm{pH}$ stable. The leaves of the plant have a pleasantly sweet and refreshing taste which is induced by diterpene glycosides (stevioside and rebaudiosides), a highpotency sweeteners and substitute to sugar, being 300 times sweeter than sucrose (Madan et al., 2010; Megeji et al., 2005; Singh and Rao, 2005; Soejarto et al., Yadav et al., 2011). Sugar obtained from leaves of Stevia containing compounds about 250 times as sweet as table sugar (Shock, 1982) and 300 times sweeter than sucrose (Noshiyama et al.,1991). It was first recognized by Bertoni who later studied it and found that the plant was new to science, which he renamed as Stevia rebaudiana, Bertoni Stevia rebaudiana, Bert. Stevia is a genus of about 200 species of herbs and shrubs in the sunflower family (Asteraceae), and originated from South America. (Soejarto 2002), It's a natural sweet herb native of northeastern Paraguay and today it is cultivated around the world (Savita et al., 2004). Stevia is a diploid plant, having 11 pairs of chromosome (Frederico et al., 1996) with critical day length of 13 hours (Zaidan et al., 1980) and its cultivation has spread worldwide. this line present investigation is initiated with the following objectives. To know the effect of different levels of nitrogen on growth and yield of stevia, tested Varieties effect on growth and yield of stevia and the interaction effects of different levels of nitrogen and tested Varieties s growth and yield of stevia.

\section{Materials and methods}

The present work was designed to study the variety and nitrogen levels on botanical and chemical traits of stevia (stevia rebaudiana, Bertani). Two experiments were carried out at Giza Experimental Station, Agricultural Research Center, Egypt during $2015 / 2016$ and 2016/2017 growing seasons. The experimental treatments the combinations of three nitrogen levels and four tested varieties as follow:

\section{Treatments}

Two factors were studied as follow:

A: nitrogen fertilizer levels (N)

$\mathrm{N} 1=20 \mathrm{~kg} \mathrm{~N}$ fed/cut., $\mathrm{N} 2=30 \mathrm{~kg} \mathrm{~N}$ fed/cut. and $\mathrm{N} 3$ $=40 \mathrm{~kg} \mathrm{~N}$ fed/cut.

B: Varieties (v):

$\mathrm{V} 1=$ China $1, \mathrm{~V} 2=$ Egy1, V3 = spanti and V4 = shou 2

Nitrogen fertilizer was in the form urea $(46,5 \% \mathrm{~N})$ and added in two equalra, rates the first rates was applied after 15 days from transplanting and the second dose was applied after 15 days from the first one. In the next cuts, the first dose was applied 15 days after cutting and the second rates was applied 15 days later. Potassium fertilizer was applied as potassium sulphate $\left(48 \% \quad \mathrm{~K}_{2} \mathrm{O}\right)$ at the rate of $50 \mathrm{~kg} / \mathrm{fed}$ were during land preparation. Calcium superphosphate $\left(\begin{array}{lll}15.5 \% & \mathrm{P}_{2} \mathrm{O}_{5}\end{array}\right)$ rate of $50 \mathrm{~kg} / \mathrm{fed}$ were during land preparation.

\section{Field Experimental Design:}

The experimental design used was a split plot design with three replicates. Fertilizer levels were arranged in the main plots and cultivars in the sub plots. The sub plot area was $10.8 \mathrm{~m} 2$ (6 ridges) 3.0 meters in length and $60 \mathrm{~cm}$ in width. 
Table A. Physical and Chemical analysis of experimental soils in 2015/2016and 2016/2017 seasons.

\begin{tabular}{|c|c|c|}
\hline \multirow[t]{2}{*}{ Analysis } & \multicolumn{2}{|l|}{ Seasons } \\
\hline & $2015 / 2016$ & $2016 / 2017$ \\
\hline \multicolumn{3}{|l|}{ Mechanical analysis } \\
\hline Coasre sand \% & 0.20 & 0.50 \\
\hline Fine sand $\%$ & 12.16 & 14.2 \\
\hline Silt \% & 48.85 & 45.7 \\
\hline Clay $\%$ & 38.99 & 36.5 \\
\hline Textual class & Cilt clay loam & Cilt clay loam \\
\hline \multicolumn{3}{|l|}{ Chemical analysis } \\
\hline Organic matter \% & 1.08 & 1.32 \\
\hline $\mathrm{CaCo} 3 \%$ & 1.10 & 2.0 \\
\hline $\mathrm{PH}(1: 2.5)^{* *}$ & 8.10 & 8.0 \\
\hline Soluble Ca++ (meq /100 g soil ) & 11.2 & 16.2 \\
\hline Soluble Mg++ (meq /100 g soil ) & 10.7 & 14.7 \\
\hline Soluble $\mathrm{Na}+(\mathrm{meq} / 100 \mathrm{~g}$ soil $)$ & 8.3 & 11.7 \\
\hline Soluble $\mathrm{K}+(\mathrm{meq} / 100 \mathrm{~g}$ soil $)$ & 4.1 & 2.6 \\
\hline Soluble Co3 --(meq /100 g soil ) & -- & -- \\
\hline Soluble Hco 3--(meq /100 g soil ) & 3.5 & 5.6 \\
\hline Soluble Cl--(meq /100 g soil ) & 13.3 & 17.9 \\
\hline Soluble So4--(meq /100 g soil ) & 17.3 & 31.7 \\
\hline Available N(ppm) & $11.00 \%$ & $13.9 \%$ \\
\hline Available P( ppm) & $9.12 \%$ & $11 \%$ \\
\hline Available K(ppm ) & $35.86 \%$ & $34.1 \%$ \\
\hline
\end{tabular}

\section{Studied characters}

-plant height $(\mathrm{cm})$.

- number of main branches /plant.

-Plant fresh weight $(\mathrm{g})$

-Plant dry weight $(\mathrm{g})$.

- Leaves fresh weight $(\mathrm{g}) /$ plant.

-Dry leaves weight $(\mathrm{g}) /$ plant. Leaves were dried under shade and kept at 60C for one hour in oven.

- leaves fresh weigh yield ( $\mathrm{t} / \mathrm{cut} / \mathrm{fed}$ ).

- Dry leaves yield (ton/fed. cut)

- Dry leaves yield (ton/fed. Seasons). Total of the three cuts

\section{Statistical analysis:}

All collected data were statistically analyzed according to technique of analysis of variance for split- plot design by " GENSTAT Version $12^{\text {th }} 2009$ " computer software package (VSN International, Hemel Hempstead, UK) to determine The differences among treatment means were compared by L.S.D. test at $P \leq 0.05$ Payne, et al (2009). Combined analysis for the two seasons of experimentation was done according to the homogeneity of experimental error variance (Bartlett, 1937).

\section{Results and Discussion}

\section{Effect of nitrogen fertilizer levels}

Results in Table (1, 2, 3 and 4) indicate that plant height, number of main branches per plant, plant fresh weight, plant dry weight, leaves fresh weight per plant, dry leaves weight per plant, leaves fresh weigh yield, dry leaves yield and total leaves yield were significantly affected by increasing nitrogen fertilizer levels in the first and second seasons. The highest nitrogen rate of $40 \mathrm{~kg} \mathrm{~N} / \mathrm{fed} /$ cut gave the highest values as compared where the other nitrogen treatments of all studied characters in both seasons 
Table 1. Effect of nitrogen fertilizer levels on plant height, number of main branches per plant, plant fresh weight, plant dry weight of stevia in $2015 / 2016$ season.

\section{Season 2015/2016 \\ Treatment}

$$
\text { plant height }(\mathbf{c m})
$$

$$
\text { Number of main branches Plant fresh weight }(\mathrm{g})
$$

\section{Plant dry weight $(\mathbf{g})$}

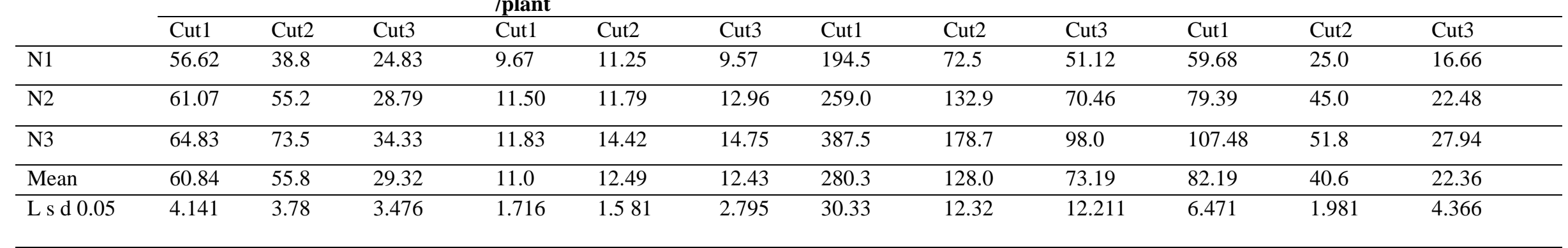

N1: $20 \mathrm{~kg} \mathrm{~N}$ fed/cut. , N2: $30 \mathrm{~kg} \mathrm{~N}$ fed/cut , N3: $40 \mathrm{~kg} \mathrm{~N}$ fed/cut.

Table 2. Effect nitrogen fertilizer levels on plant height, number of main branches per plant, plant fresh weight, plant dry weight of stevia in $2016 / 2017$ seasons.

\section{6/2017 Season}

\begin{tabular}{|c|c|c|c|c|c|c|c|c|c|c|c|c|}
\hline & \multicolumn{3}{|c|}{ plant height $(\mathrm{cm})$} & \multicolumn{3}{|c|}{ Number of main branches /plant } & \multicolumn{3}{|c|}{ Plant fresh weight (g) } & \multicolumn{3}{|c|}{ Plant dry weigh (g) } \\
\hline & Cut1 & Cut2 & Cut3 & Cut1 & Cut2 & Cut3 & Cut1 & Cut2 & Cut3 & Cut1 & Cut2 & Cut3 \\
\hline N1 & 43.57 & 34.58 & 36.12 & 12.94 & 10.92 & 14.72 & 209.0 & 47.57 & 124.8 & 63.13 & 15.80 & 33.52 \\
\hline $\mathrm{N} 2$ & 47.27 & 35.25 & 41.44 & 13.50 & 12.42 & 16.08 & 265.3 & 64.34 & 149.1 & 80.66 & 20.23 & 42.94 \\
\hline N3 & 56.47 & 39.82 & 46.8 & 15.25 & 14.25 & 18.00 & 371.4 & 91.78 & 218.5 & 107.72 & 27.10 & 53.82 \\
\hline Mean & 49.1 & 36.55 & 41.46 & 13.33 & 12.53 & 16.27 & 281.9 & 67.90 & 164.1 & 83.83 & 21.04 & 43.42 \\
\hline L s d 0.05 & 4.95 & 4.334 & 3.63 & 0.896 & 2.026 & 1.583 & 22.68 & 10.481 & 10.61 & 5.385 & 2.33 & 3.413 \\
\hline
\end{tabular}

\section{Treatment}

N1: $20 \mathrm{~kg} \mathrm{~N}$ fed/cut., N2: $30 \mathrm{~kg} \mathrm{~N}$ fed/cut, N3: $40 \mathrm{~kg} \mathrm{~N} \mathrm{fed/cut.}$ 
Table 3. Effect nitrogen fertilizer levels on fresh weight per plant, dry leaves weight per plant, leaves fresh weigh yield, dry leaves yield and total leaves yield of stevia 2015/2016 season.

\begin{tabular}{|c|c|c|c|c|c|c|c|c|c|c|c|c|c|}
\hline \multirow{3}{*}{ Treatment } & \multicolumn{13}{|c|}{ 2015/2016 Season } \\
\hline & \multicolumn{3}{|c|}{ Leaves fresh weight /plant (g) } & \multicolumn{2}{|c|}{$\begin{array}{l}\text { Dry leaves } \\
\text { plant(g) }\end{array}$} & weight per & \multicolumn{2}{|c|}{$\begin{array}{l}\text { Leaves fresh weigh } 1 \\
\text { cut / fed }\end{array}$} & \multirow{2}{*}{$\begin{array}{l}\text { yield t/ } \\
\text { Cut3 }\end{array}$} & \multicolumn{3}{|c|}{ Dry leaves yield $t /$ cut/ fed } & \multirow[t]{2}{*}{$\begin{array}{l}\text { Total yield t/ } \\
\text { fed /year }\end{array}$} \\
\hline & Cut1 & Cut2 & Cut3 & Cut1 & Cut2 & Cut3 & Cut1 & Cut2 & & Cut1 & Cut2 & Cut3 & \\
\hline N1 & 111.0 & 34.0 & 30.9 & 31.32 & 9.87 & 9.07 & 3.323 & 1.020 & 0.931 & 1.250 & 0.357 & 0.48 & 2.087 \\
\hline $\mathrm{N} 2$ & 161.6 & 49.8 & 43.28 & 45.87 & 13.47 & 12.54 & 4.743 & 1.494 & 1.304 & 1.697 & 0.495 & 0.552 & 2.743 \\
\hline N3 & 257.2 & 84.0 & 60.38 & 65.47 & 21.43 & 15.43 & 7.696 & 2.524 & 1.824 & 2.179 & 0.705 & 0.756 & 2.743 \\
\hline Mean & 176.6 & 55.9 & 44.84 & 47.56 & 9.87 & 12.35 & 4.615 & 1.679 & 1.353 & 1.709 & 0.519 & 0.6 & 2.824 \\
\hline $\mathrm{Ls} \mathrm{d} 0.05$ & 25.88 & 6.9 & 7.579 & 3.95 & 1.16 & 2.4 & 0.689 & 0.205 & 0.230 & 0.223 & 0.032 & 0.079 & 0.2622 \\
\hline
\end{tabular}

N1: $20 \mathrm{~kg} \mathrm{~N}$ fed/cut., N2: $30 \mathrm{~kg} \mathrm{~N}$ fed/cut, N3: $40 \mathrm{~kg} \mathrm{~N}$ fed/cut

Table 4. Effect nitrogen fertilizer levels on fresh weight per plant, dry leaves weight per plant, leaves fresh weigh yield, dry leaves yield and total leaves yield of stevia in 2016/2017 season.

\begin{tabular}{|c|c|c|c|c|c|c|c|c|c|c|c|c|c|}
\hline \multirow{3}{*}{ Treatment } & \multicolumn{13}{|c|}{ 2016/2017 Season } \\
\hline & \multicolumn{3}{|c|}{$\begin{array}{l}\text { Leaves fresh weigh } \\
\text { /plant(g) }\end{array}$} & \multicolumn{3}{|c|}{ Dry leaves weight / plant(g) } & \multirow{2}{*}{$\begin{array}{l}\text { Leaves } \\
\text { / fed } \\
\text { Cut1 }\end{array}$} & \multicolumn{2}{|c|}{ fresh weight yield t/cut } & \multicolumn{3}{|c|}{ Dry leaves yield t/cut/ fed } & \multirow[t]{2}{*}{$\begin{array}{l}\text { Total leaves } \\
\text { yield ton/year }\end{array}$} \\
\hline & Cut1 & Cut2 & Cut3 & Cut1 & Cut2 & Cut3 & & Cut2 & Cut3 & Cut1 & Cut2 & Cut3 & \\
\hline N1 & 131.4 & 23.71 & 75.4 & 37.5 & 6.84 & 18.5 & 3.971 & 0.713 & 2.33 & 1.854 & 0.432 & 0.637 & 2.651 \\
\hline N2 & 177.3 & 29.73 & 93.0 & 50.98 & 8.22 & 28.1 & 5.385 & 0.889 & 2.79 & 1.900 & 0.629 & 0.911 & 3.088 \\
\hline N3 & 254.3 & 46.85 & 134.3 & 70.64 & 12.78 & 29.5 & 7.752 & 1.407 & 3.93 & 2.518 & 0.814 & 1.118 & 4.025 \\
\hline Mean & 187.6 & 33.43 & 101.0 & 52.99 & 9.28 & 25.4 & 5.702 & 1.003 & 3.02 & 2.091 & 0.625 & 0.889 & 3.255 \\
\hline L s d 0.05 & 11.37 & 5.77 & 11.45 & 3.79 & 1.18 & 2.95 & 0.481 & 0.167 & 0.776 & 0.132 & 0.032 & 0.139 & 0.2538 \\
\hline
\end{tabular}

N1: $20 \mathrm{~kg} \mathrm{~N} \mathrm{fed/cut.,}$ 
The highest plant height $(\mathrm{cm})$ values were recorded for the three cuts respectively, in 2015/2016 and 2016/2017 season by adding nitrogen rate of $40 \mathrm{~kg}$ $\mathrm{N} / \mathrm{fed} /$ cut. These results are in agreement with Maheshwar (2005). Number of main branches recorded for the three cuts in the first and second season. The highest nitrogen rate of $40 \mathrm{~kg} \mathrm{~N}$ fed/cut. gave the highest values of plant fresh weight $(\mathrm{g})$ recorded for all cuts respectively in the first and in the second season. The maximum values of plant dry weight $(\mathrm{g})$ recorded for the three cuts respectively in 2015/2016 and 2016/2017season were recorded when nitrogen rate of $40 \mathrm{~kg} \mathrm{~N} / \mathrm{fed} /$ cut was applied. The highest values of leaves fresh weight per plant were obtained under the highest nitrogen rate of $40 \mathrm{~kg} \mathrm{~N} / \mathrm{fed}$ /cut as compared with the other nitrogen treatments for the three cuts respectively in 2015/2016 and 2016/2017season. Dry leaves weight per plant recorded for the three cuts respectively in 2015/2016 and 2016/2017season were accomplished by adding nitrogen rate of $40 \mathrm{~kg} \mathrm{~N} / \mathrm{fed} /$ cut. Also, the highest nitrogen rate of $40 \mathrm{~kg}$. $\mathrm{N} / \mathrm{fed} / \mathrm{cut}$ produced the highest values of leaves fresh weight yield ( $t /$ fed ) recorded for all cuts respectively in 2015/2016 and $2016 / 2017$ season in the second season. The current work is in agreement with Attia (2005). The maximum values of dry leaves yield ( $\mathrm{t} / \mathrm{cut} / \mathrm{fed}$ ) recorded for the three cuts respectively in 2015/2016 and 2016/2017season after applying nitrogen rate of $40 \mathrm{~kg} \mathrm{~N} / \mathrm{fed} /$ cut. The current work is in agreement with Allam et al 2001 and Attia (2005). The highest nitrogen rate $40 \mathrm{~kg}$. $\mathrm{N} /$ fed. produced the highest values of total leaves yield ton/year as compared with the other nitrogen treatments in the first and second seasons. On the other hand, the lowest nitrogen rate 20 $\mathrm{kg}$. N/fed cut produced the lowest values of all studied characters in both seasons.

\section{Discussion}

Data showed that all stevia characters were significantly affected by nitrogen levels in both seasons.Nitrogen levels from 20to 30 and $40 \mathrm{~kg}$ .N/fed/ cut these increases may by attributed to the increase in meristemic activity as well as the production of ouxin which encourage cell elongation .on the other hand, nitrogen deficiency inhabit metabolism and c meristemic activity in plant. These results are in agreement with those obtained by Allam et al 2001 and Attia (2005).

\section{Effect of Varieties}

Data presented in Table (5, 6,7 and 8) indicate clearly that stevia varieties have significant different in Plant height $\mathrm{cm}$, number of main branches /plant, plant fresh weight (g), dry weight of plant $(\mathrm{g})$, leaves fresh weight per plant $(\mathrm{g})$, dry leaves weight, leaves fresh weight yield $\mathrm{t} / \mathrm{cut} / \mathrm{fed}$, dry leaves weight yield $\mathrm{t} / \mathrm{cut} / \mathrm{fed}$ and total leaves yield ton/year in the first and second seasons. Egy1 varieties gave the highest values surpassing the other varieties except plant height, number of main branches /plant were Spanti varieties gave the highest values for these traits in the first and second seasons.

Egy1 varieties produced the highest values of plant fresh weight $(\mathrm{g})$ in the first and the second season. The current work is in agreement with Nitu et al (2013) results. The highest values of plant dry weight were produced from Egy1 varieties in the three cuts respectively in the first and second season. Egy1 varieties produced the highest values of leaves fresh weight $(\mathrm{g})$ for all cuts respectively in the first season and second season. These results are in agreement with Asmaa Haraz (2016). The highest values of dry leaves weight ( $\mathrm{g}$ ) were produced from Egy1 varieties for the three cuts respectively in the first and second season. The current work results are in agreement with those found by Asmaa Haraz(2016) and Anami et al., (2010). Egy1 varieties produced the highest values of fresh weight yield (t /cut/ fed) for the three cuts, respectively in the first and in the second season. These results are in agreement with Metivier and Viana (1979). The highest values of leaves yield ( $\mathrm{t} /$ cut / fed) were produced from Egy1 varieties for the three cuts respectively in the first season and second season. These results are in agreement with Brandle and Rosa(1992), Shizhen and Wanzhong (1988) and Chalapathi et al., (1999). Egy1 Varieties produced the highest value of total leaves yield ( $\mathrm{t}$ cut /year) respectively, in the first and second seasons.

Meanwhile, Spanti varieties produced the highest values of plant height for the three cuts respectively in the first and, in the second season. These results are in agreement with Asmaa Haraz(2016), Anami et al (2010), Chalapathiet al (1999) and Nitu et al (2013). Spanti varieties produced the highest values of number of main branches for the three cuts respectively, in the first and second seasons. These results are in agreement with those found by Anami et al (2010) and Nitu et al (2013)

\section{Discussion}

Such variation might reflect the efficiency of plant building metabolites or might be ascribed to genetical differences. These results are in agreement with those found by Asmaa Haraz(2016), Anamiet al (2010) and Nituet al (2013) 
Table 5. Effect Varieties on plant height, number of main branches per plant, plant fresh weight, plant dry weight of stevia in 2015/2016 season.

\begin{tabular}{|c|c|c|c|c|c|c|c|c|c|c|c|c|}
\hline \multirow{3}{*}{ Treatment } & \multicolumn{12}{|c|}{$2015 / 2016$ Season } \\
\hline & \multicolumn{3}{|c|}{ Plant height $(\mathbf{c m})$} & \multicolumn{3}{|c|}{ Number of main branches /plant } & \multicolumn{3}{|c|}{ Plant fresh weight $(\mathrm{g})$} & \multicolumn{3}{|c|}{ Plant dry weigh (g) } \\
\hline & Cut1 & Cut2 & Cut3 & Cut1 & Cut2 & Cut3 & Cut1 & Cut2 & Cut3 & Cut1 & Cut2 & Cut3 \\
\hline V1 & 58.40 & 51.2 & 31.78 & 10.00 & 11.67 & 12.42 & 350.2 & 149.5 & 72.02 & 103.90 & 49.39 & 22.26 \\
\hline $\mathrm{V} 2$ & 58.53 & 54.3 & 23.50 & 11.22 & 13.17 & 14.00 & 387.4 & 194.1 & 108.08 & 106.23 & 57.11 & 31.36 \\
\hline V3 & 74.44 & 67.2 & 37.00 & 14.78 & 18.78 & 15.94 & 174.73 & 104.0 & 48.71 & 57.96 & 35.50 & 16.39 \\
\hline V4 & 52.00 & 50.4 & 25.00 & 8.00 & 6.33 & 7.33 & 208.9 & 64.6 & 63.96 & 60.66 & 20.24 & 19.44 \\
\hline Mean & 60.84 & 55.8 & 29.32 & 11.00 & 12.49 & 12.43 & 280.3 & 128.0 & 73.19 & 82.19 & 40.6 & 22.36 \\
\hline L s d 0.05 & 4.619 & 7.10 & 2.866 & 1.175 & 1.178 & 1.029 & 18.94 & 8.49 & 5.580 & 5.135 & 3.055 & 1.555 \\
\hline
\end{tabular}

Table 6. Effect Varieties on plant height, number of main branches per plant, plant fresh weight, plant dry weight of stevia in 2016/2017season

\section{6/2017 Season \\ Treatment}

\section{Plant height(cm)}

\begin{tabular}{|c|c|c|c|c|c|c|c|c|c|c|c|c|}
\hline & Cut1 & Cut2 & Cut3 & Cut1 & Cut2 & Cut3 & Cut1 & Cut2 & Cut3 & Cut1 & Cut2 & Cut3 \\
\hline V1 & 45.73 & 39.22 & 42.40 & 12.94 & 11.67 & 15.56 & 292.8 & 79.13 & 165.2 & 92.54 & 25.02 & 45.03 \\
\hline $\mathrm{V} 2$ & 46.44 & 34.67 & 40.53 & 15.06 & 12.89 & 16.51 & 412.7 & 90.46 & 214.8 & 116.92 & 27.29 & 52.96 \\
\hline V3 & 60.61 & 42.52 & 47.67 & 16.99 & 18.56 & 22.0 & 227.1 & 56.83 & 146.3 & 69.57 & 18.21 & 41.4 \\
\hline V4 & 43.61 & 29.78 & 35.22 & 8.33 & 7.00 & 11.0 & 195 & 45.18 & 130.3 & 56.30 & 13.64 & 34.31 \\
\hline Mean & 49.10 & 36.55 & 41.46 & 13.33 & 12.53 & 16.27 & 281.9 & 67.90 & 164.1 & 83.83 & 21.04 & 43.42 \\
\hline L s d 0.05 & 4.283 & 2.413 & 2.782 & 1.068 & 1.495 & 1.871 & 14.86 & 3.815 & 10.03 & 4.080 & 1.419 & 2.493 \\
\hline
\end{tabular}

V1: China 1, V2 Egy1:

,V3: Spanti ,

V4: Shou2 
Table 7. the of effect Varieties on fresh weight per plant, dry leaves weight per plant, leaves fresh weigh yield, dry leaves yield and total leaves yield of stevia in 2015/2016season.

\begin{tabular}{|c|c|c|c|c|c|c|c|c|c|c|c|c|c|}
\hline \multirow{3}{*}{ Treatment } & \multicolumn{13}{|c|}{ 2015/2016 Season } \\
\hline & \multicolumn{3}{|c|}{ Leaves fresh weigh / plant (g) } & \multicolumn{3}{|c|}{ Dry leaves weight/ plant (g) } & \multicolumn{3}{|c|}{ Leaves fresh yield t/cut/ fed } & \multicolumn{3}{|c|}{ Leaves yield $t / c u t /$ fed } & \multirow{2}{*}{$\begin{array}{l}\text { Total leaves } \\
\text { yiedt cut /year }\end{array}$} \\
\hline & Cut1 & Cut2 & Cut3 & Cut1 & Cut2 & Cut3 & Cut1 & Cut2 & Cut3 & Cut1 & Cut2 & Cut3 & \\
\hline V1 & 231.6 & 65.79 & 46.38 & 62.63 & 19.09 & 12.94 & 6.512 & 1.975 & 1.396 & 2.096 & 0.615 & 0.644 & 3.355 \\
\hline $\mathrm{V} 2$ & 244.2 & 100.2 & 68.63 & 63.39 & 48.29 & 17.97 & 7.72 & 3.011 & 2.074 & 2.247 & 0.894 & 0.752 & 3.894 \\
\hline V3 & 90.0 & 30.09 & 21.82 & 25.51 & 8.79 & 6.39 & 2.69 & 1.050 & 0.662 & 1.102 & 0.229 & 0.398 & 1.729 \\
\hline V4 & 140.5 & 27.56 & 42.52 & 38.69 & 7.07 & 12.09 & 4.23 & 1.206 & 1.279 & 1.390 & 0.337 & 0.59 & 2.316 \\
\hline Mean & 176.6 & 55.91 & 44.84 & 47.56 & 14.92 & 12.35 & 4.615 & 1.679 & 1.353 & 1.709 & 0.519 & 0.6 & 2.824 \\
\hline L s d 0.05 & 19.38 & 5.43 & 5.52 & 5.491 & 2.62 & 1.39 & 0.482 & 0.167 & 0.163 & 0.331 & 0.045 & 0.039 & 0.3408 \\
\hline
\end{tabular}

Table 8. the of effect Varieties on fresh weight per plant, dry leaves weight per plant, leaves fresh weigh yield, dry leaves yield and total leaves yield of stevia in $2016 / 2017$ season.

\begin{tabular}{|c|c|c|c|c|c|c|c|c|c|c|c|c|c|}
\hline \multirow{3}{*}{$\begin{array}{l}\text { Treat } \\
\text { ment }\end{array}$} & \multicolumn{13}{|c|}{ 2016/2017 Season } \\
\hline & \multicolumn{3}{|c|}{ Leaves fresh weigh /plant (g) } & \multicolumn{3}{|c|}{ Dry leaves weight/plant(g) } & \multicolumn{3}{|c|}{ fresh weigh yield $t / c u t /$ fed } & \multicolumn{3}{|c|}{ Leaves yield $t /$ cut / fed } & \multirow{2}{*}{$\begin{array}{l}\text { Total leaves } \\
\text { yiedton/year }\end{array}$} \\
\hline & Cut1 & Cut2 & Cut3 & Cut1 & Cut2 & Cut3 & Cut1 & Cut2 & Cut3 & Cut1 & Cut2 & Cut3 & \\
\hline V1 & 207.3 & 37.69 & 106.1 & 60.68 & 10.89 & 25.20 & 6.234 & 1.134 & 3.18 & 2.495 & 0.757 & 0.892 & 3.717 \\
\hline $\mathrm{V} 2$ & 284.7 & 47.79 & 137.4 & 77.79 & 13.13 & 29.82 & 8.742 & 1.431 & 4.13 & 2.761 & 0.753 & 1.323 & 4.442 \\
\hline $\mathrm{V} 3$ & 133.4 & 23.78 & 71.7 & 38.41 & 6.61 & 18.6 & 3.714 & 0.712 & 2.22 & 1.578 & 0.513 & 0.545 & 1.889 \\
\hline V4 & 125.2 & 24.47 & 88.0 & 35.08 & 6.50 & 27.9 & 4.119 & 0.735 & 2.55 & 1.936 & 0.477 & 0.796 & 2.970 \\
\hline Mean & 187.6 & 33.43 & 101. & 52.99 & 9.28 & 25.4 & 5.702 & 1.003 & 3.02 & 2.091 & 0.625 & 0.889 & 3.255 \\
\hline L s d 0.05 & 12.73 & 2.673 & 8.41 & 3.506 & 0.893 & 2.159 & 0.369 & 0.078 & 0.671 & 0.231 & 0.044 & 0.152 & 0.294 \\
\hline
\end{tabular}

\begin{tabular}{llll}
\hline V1: China 1 & V2: Egy1 & V3: Spanti, & V4 : Shou 2
\end{tabular}




\section{Effect of interaction effect between nitrogen fertilizer levels and cultivars}

Data in Table $(9,10,11$ and 12) shows that the interaction effect between nitrogen fertilizer levels and stevia varieties that were significant for plant height $\mathrm{cm}$, number of main branches /plant, fresh weight $(\mathrm{g})$, dry weight per plant $(\mathrm{g})$, leaves fresh weight yield (ton/ fed), leaves yield (ton / fed) and total leaves yield (ton/year). In the first and second seasons, nitrogen fertilizer levels $40 \mathrm{~kg} \mathrm{~N} / \mathrm{fed} / \mathrm{cut}$ and egy1 varieties gave the highest values in the three cuts for all studied characters except plant height and number of main branches where nitrogen fertilizer level of $40 \mathrm{~kg} \mathrm{~N} / \mathrm{fed} / \mathrm{cut}$ and Spanti varieties gave highest values .

Adding $40 \mathrm{~kg} \mathrm{~N} /$ fed / cut to egyl varieties recorded the highest values of plant fresh weight $(\mathrm{g})$ for all cuts respectively in the first and the second season. the highest values of plant dry weight (g) were attained by treating Egy1 varieties with nitrogen rate of $40 \mathrm{~kg} \mathrm{~N} / \mathrm{fed} /$ cut in all cuts respectively in the first and the second season. Adding $40 \mathrm{~kg}$. N /fed / cut to egy 1 varieties recorded the highest values of leaves fresh weight / plant(g) for all cuts respectively in the first and the second season. The highest values of dry leaves weight/ plant (g) were obtained by treating Egy1 varieties with nitrogen rate of $40 \mathrm{~kg} \mathrm{~N}$ /fed / cut for all cuts respectively in the first and respectively in the second season. At the same trend, adding 40kg. $\mathrm{N} /$ fed / cut to Egy1 varieties recorded the highest values of fresh weight yield ( $/$ /cut/ fed) for the three cuts, respectively in the first and second season. The of highest values of leaves yield ( $\mathrm{t} / \mathrm{cut} /$ fed) were obtained by treating Egy1 varieties with nitrogen rate of $40 \mathrm{~kg} \mathrm{~N} /$ fed / cut for all cuts, respectively in the first and second season. The highest values of total leaves yield ( $t /$ cut /year) highest values were obtained by treating Egy1 varieties with nitrogen rate of $40 \mathrm{~kg} \mathrm{~N} / \mathrm{fed} /$ cut respectively, in the first and second seasons.

.Mean while, Spanti varieties treated with nitrogen rate of $40 \mathrm{~kg} \mathrm{~N} / \mathrm{fed} /$ cut produced the highest values of plant height $(\mathrm{cm})$ of the all cuts in the first and second season. Spanti varieties and nitrogen rate of 40 $\mathrm{kg} \mathrm{N} /$ fed / cut produced the highest values of number of main branches for the three cuts, respectively in the first and second seasons.

Nitrogen fertilizer level of $20 \mathrm{~kg} \mathrm{~N} / \mathrm{fed} / \mathrm{cut}$ added to Shou 2 varieties gave the lowest values of plant height, number of main branches, fresh weight of plant $(\mathrm{g})$, dry weight of plant $(\mathrm{g})$, plant height $\mathrm{cm}$, number of main branches, fresh weight of plant $(\mathrm{g})$ and dry weight of plant $(\mathrm{g})$ except plant height in cut 1 in the second seasons. while nitrogen fertilizer level of $20 \mathrm{~kg} \mathrm{~N} / \mathrm{fed} /$ cut and Spanti varieties gave the lowest value of leaves fresh weight per plant $(\mathrm{g})$, dry leaves weight and total leaves yield (ton/year) while adding $20 \mathrm{~kg}$. N /fed / cut to Shou 2 Varieties recorded (cut 2 in the first season and cut 1 and cut 3 in the second season) the lowest values in plant height, respectively. While the lowest values of plant height were recorded when fertilization level of $20 \mathrm{~kg}$.N/ fed /cut was applied to Shou2 varieties in the first and second seasons .respectively. 
Table 9. Effect interaction effect between nitrogen fertilizer levels and Varieties on plant height, number of main branches per plant, plant fresh weight, plant dry weight of stevia in 2015/2016 season.

\begin{tabular}{|c|c|c|c|c|c|c|c|c|c|c|c|c|}
\hline \multirow{3}{*}{ treatment } & \multicolumn{12}{|c|}{ 2015/2016 Season } \\
\hline & \multicolumn{3}{|c|}{ Plant height(cm) } & \multicolumn{3}{|c|}{ numberof main branches /plant } & \multicolumn{3}{|c|}{ Plant fresh weight (g) } & \multicolumn{3}{|c|}{ Plant dry weigh (g) } \\
\hline & Cut1 & Cut2 & Cut3 & Cut1 & Cut2 & Cut3 & Cut1 & Cut2 & Cut3 & Cut1 & Cut2 & Cut3 \\
\hline N1V1 & 54.77 & 31.3 & 27.0 & 9.00 & 10.67 & 8.77 & 219.6 & 75.0 & 61.57 & 67.17 & 26.30 & 19.67 \\
\hline N1V2 & 53.90 & 32.7 & 20.67 & 10.0 & 12.00 & 10.0 & 262.5 & 103.2 & 75.67 & 77.27 & 34.9 & 24.72 \\
\hline N1V3 & 71.50 & 59.0 & 32.67 & 13.67 & 17.33 & 14.67 & 139.9 & 71.7 & 32.33 & 48.17 & 25.8 & 11.67 \\
\hline N1V4 & 46.33 & 32.0 & 19.0 & 6.00 & 5.00 & 4.67 & 155.8 & 40.1 & 34.90 & 46.13 & 12.8 & 11.03 \\
\hline $\mathrm{N} 2 \mathrm{~V} 1$ & 61.43 & 53.3 & 33.0 & 10.0 & 11.00 & 13.83 & 369.5 & 169.1 & 72.80 & 114.1 & 58.57 & 22.80 \\
\hline $\mathrm{N} 2 \mathrm{~V} 2$ & 61.67 & 52.3 & 24.83 & 11.00 & 12.83 & 16.00 & 334.0 & 181.8 & 97.37 & 101.3 & 58.5 & 30.87 \\
\hline $\mathrm{N} 2 \mathrm{~V} 3$ & 71.50 & 60.0 & 36.33 & 14.67 & 18.33 & 14.67 & 166.0 & 114.4 & 49.03 & 53.43 & 40.1 & 16.73 \\
\hline $\mathrm{N} 2 \mathrm{~V} 4$ & 51.33 & 55.0 & 21.0 & 10.0 & 5.00 & 7.33 & 166.3 & 66.4 & 62.63 & 48.73 & 22.7 & 19.53 \\
\hline N3V1 & 59.00 & 69.0 & 35.33 & 11.0 & 13.33 & 14.67 & 461.4 & 204.3 & 81.70 & 103.90 & 63.3 & 24.30 \\
\hline N3V2 & 61.67 & 78.0 & 25.00 & 12.33 & 14.67 & 16.00 & 565.7 & 297.2 & 151.20 & 140.13 & 78.0 & 38.93 \\
\hline N3V3 & 80.33 & 82.7 & 42.00 & 16.00 & 20.67 & 18.33 & 218.3 & 125.8 & 64.77 & 72.27 & 40.6 & 20.77 \\
\hline N3V4 & 58.33 & 64.3 & 35.00 & 8.00 & 9.00 & 10.00 & 304.5 & 87.3 & 94.33 & 87.1 & 25.2 & 27.77 \\
\hline Mean & 60.84 & 55.8 & 29.32 & 11.0 & 12.49 & 12.43 & 280.3 & 128.0 & 73.19 & 82.19 & 40.6 & 22.36 \\
\hline L s d 0.05 & 7.507 & 10.95 & 4.99 & 2.185 & 2.121 & 2.827 & 36.70 & 15.75 & 12.988 & 9.049 & 4.773 & 4.393 \\
\hline $\begin{array}{l}\text { N1: } 20 \mathrm{~kg} \mathrm{~N} \mathrm{f} \\
\text { V1: China } 1\end{array}$ & $\begin{array}{l}\text { cut., } \\
\text { V2: }\end{array}$ & & $\begin{array}{r}\text { N2: } 30 \\
\text { V3 }\end{array}$ & ti , & & $\begin{array}{l}\mathrm{N} \text { fed// } \\
\text { ou } 2\end{array}$ & & & & & & \\
\hline
\end{tabular}


Table 10. Effect interaction effect between nitrogen fertilizer levels and Varieties on plant height, number of main branches per plant, plant fresh weight, plant dry weight of stevia in 2016/2017 season.

\begin{tabular}{|c|c|c|c|c|c|c|c|c|c|c|c|c|}
\hline \multirow[b]{3}{*}{ Treatmeant } & \multicolumn{12}{|c|}{ 2016/2017 Season } \\
\hline & \multicolumn{3}{|c|}{ Plant height(cm) } & \multicolumn{3}{|c|}{ numberof main branches /plant } & \multicolumn{3}{|c|}{ Plant fresh weight (g) } & \multicolumn{3}{|c|}{ Plant dry weight (g) } \\
\hline & Cut1 & Cut2 & Cut3 & Cut1 & Cut2 & Cut3 & Cut1 & Cut2 & Cut3 & Cut1 & Cut2 & Cut3 \\
\hline N1V1 & 37.00 & 40.33 & 39.67 & 9.83 & 10.33 & 13.67 & 219.7 & 63.30 & 108.2 & 69.60 & 20.7 & 28.17 \\
\hline N1V2 & 43.4 & 32.33 & 35.83 & 13.83 & 12.00 & 16.67 & 321.3 & 59.30 & 179.8 & 96.07 & 19.6 & 45.63 \\
\hline N1V3 & 53.5 & 42.33 & 37.0 & 15.63 & 15.67 & 20.33 & 196.7 & 35.83 & 133.1 & 50.40 & 12.4 & 38.10 \\
\hline N1V4 & 40.33 & 23.33 & 32.0 & 5.67 & 5.67 & 9.67 & 125.2 & 31.9 & 78.2 & 36.43 & 10.6 & 38.10 \\
\hline N2V1 & 46.00 & 36.67 & 41.5 & 13.67 & 11.00 & 15.33 & 275.5 & 74.33 & 164.6 & 87.13 & 23.9 & 22.17 \\
\hline $\mathrm{N} 2 \mathrm{~V} 2$ & 50.5 & 35.00 & 39.27 & 15.00 & 13.00 & 16.67 & 404.5 & 77.7 & 187.1 & 117.7 & 24.6 & 51.23 \\
\hline N2V3 & 45.4 & 28.33 & 51.33 & 16.67 & 17.67 & 21.0 & 208.5 & 58.33 & 134.7 & 67.0 & 18.7 & 39.47 \\
\hline $\mathrm{N} 2 \mathrm{~V} 4$ & 55.67 & 28.33 & 33.67 & 8.67 & 8.00 & 11.33 & 172.8 & 47.0 & 110 & 50.80 & 13.7 & 30.1 \\
\hline N3V1 & 48.50 & 40.67 & 46.03 & 15.33 & 13.67 & 17.67 & 383.1 & 74.33 & 222.9 & 120.90 & 30.43 & 55.70 \\
\hline N3V2 & 50.5 & 35.00 & 46.50 & 16.33 & 13.67 & 17.67 & 512.3 & 134.4 & 277.4 & 137.0 & 37.7 & 62.27 \\
\hline N3V3 & 72.67 & 44.27 & 54.67 & 18.67 & 22.33 & 24.67 & 303.1 & 76.3 & 170.9 & 69.57 & 23.5 & 46.63 \\
\hline N3V4 & 48.5 & 37.67 & 40.00 & 10.67 & 7.33 & 12.00 & 287.0 & 56.7 & 202.6 & 56.30 & 16.7 & 50.67 \\
\hline mean & 49.10 & 36.55 & 41.46 & 13.33 & 12.53 & 16.27 & 281.9 & 67.90 & 164.1 & 83.83 & 21.04 & 43.42 \\
\hline L s d 0.05 & 7.356 & 4.962 & 4.899 & 1.717 & 2.701 & 3.013 & 28.17 & 10.582 & 21.77 & 7.303 & 2.783 & 4.522 \\
\hline
\end{tabular}

N1: $20 \mathrm{~kg} \mathrm{~N}$ fed/cut , N2: $30 \mathrm{~kg} \mathrm{~N}$ fed/cut

V1: China 1, V2: Egy1, V3: Spanti,

N3: $40 \mathrm{~kg} \mathrm{~N}$ fed/cut.

V4 : Shou2 
Table 11. Effect interaction effect between nitrogen fertilizer levels and Varieties on fresh weight per plant, dry leaves weight per plant, leaves fresh weigh yield, dry leaves yield and total leaves yield of stevia in 2015/2016 season.

\section{5/2016 Season}

\begin{tabular}{|c|c|c|c|c|c|c|c|c|c|c|c|c|c|}
\hline \multirow[t]{2}{*}{ treatmeant } & \multicolumn{3}{|c|}{ Leaves fresh weigh/plant (g) } & \multicolumn{3}{|c|}{ Leaves weigh/plant (g) } & \multicolumn{3}{|c|}{$\begin{array}{l}\text { L eaves fresh weight yield ton/ } \\
\text { fed }\end{array}$} & \multicolumn{3}{|c|}{ Leaves yield ton / fed } & \multirow[t]{2}{*}{$\begin{array}{l}\text { Total leaves } \\
\text { yiedt/ fed/year }\end{array}$} \\
\hline & Cut1 & Cut2 & Cut3 & Cut1 & Cut2 & Cut3 & Cut1 & Cut2 & Cut3 & Cut1 & Cut2 & Cut3 & \\
\hline N1V1 & 135.6 & 31.90 & 41.5 & 37.57 & 9.30 & 12.03 & 3.965 & 0.957 & 1.251 & 1.373 & 0.263 & 0.586 & 2.222 \\
\hline N1V2 & 144.3 & 55.50 & 50.33 & 40.67 & 16.40 & 14.93 & 4.433 & 1.668 & 1.513 & 1.7 & 0.690 & 0.619 & 3.009 \\
\hline N1V3 & 68.9 & 28.53 & 12.0 & 20.17 & 8.57 & 3.77 & 2.065 & 0.635 & 0.367 & 0.932 . & 0.172 & 0.242 & 1.346 \\
\hline N1V4 & 95.2 & 20.00 & 19.57 & 26.90 & 5.20 & 5.53 & 2.855 & 0.821 & 0.591 & 0.996 & 0.303 & 0.474 & 1.773 \\
\hline N2V1 & 237.7 & 73.47 & 45.83 & 67.43 & 21.00 & 13.33 & 5.900 & 2.207 & 1.377 & 2.314 & 0.588 & 0.479 & 3.380 \\
\hline N2V2 & 237.7 & 76.13 & 61.03 & 62.10 & 18.90 & 17.83 & 7.430 & 2.288 & 1.837 & 2.262 & 0.830 & 0.756 & 3.848 \\
\hline N2V3 & 85.4 & 26.73 & 21.93 & 22.77 & 7.90 & 6.30 & 2.536 & 0.670 & 0.667 & 0.837 & 0.221 & 0.383 & 1.443 \\
\hline $\mathrm{N} 2 \mathrm{~V} 4$ & 116.7 & 22.67 & 44.33 & 31.17 & 6.10 & 12.7 & 3.507 & 0.812 & 1.337 & 1.373 & 0.366 & 0.587 & 2.302 \\
\hline N3V1 & 321.7 & 92.00 & 51.80 & 82.90 & 26.97 & 13.47 & 9.673 & 2.763 & 1.560 & 2.601 & 0.995 & 0.867 & 4.463 \\
\hline N3V2 & 381.8 & 169.0 & 94.53 & 87.40 & 38.97 & 21.13 & 11.313 & 5.077 & 2.873 & 2.78 & 1.163 & 0.881 & 4.824 \\
\hline N3V3 & 115.6 & 35.00 & 31.53 & 33.60 & 9.90 & 9.10 & 3.470 & 0.670 & 0.952 & 1.537 & 0.296 & 0.566 & 2.399 \\
\hline N3V4 & 209.7 & 40.00 & 63.67 & 58.00 & 9.90 & 18.03 & 6.327 & 0.812 & 1.910 & 1.799 & 0.366 & 0.71 & 2.875 \\
\hline mean & 176.6 & 55.91 & 44.84 & 47.56 & 14.92 & 12.35 & 4.615 & 1.679 & 1.353 & 1.709 & 0.519 & 0.6 & 2.824 \\
\hline L s d 0.05 & 34.83 & 9.59 & 10.02 & 8.663 & 4.0 & 2.79 & 0.8893 & 0.294 & 0.299 & 0.519 & 0.071 & 0.079 & 0.542 \\
\hline
\end{tabular}

N1: $20 \mathrm{~kg} \mathrm{~N}$ fed/cut. N2: $30 \mathrm{~kg} \mathrm{~N} \mathrm{fed/cut,} \quad$ N3: $40 \mathrm{~kg} \mathrm{~N}$ fed/cut.
V1: China 1
V2: Egy1
V3: Spanti ,
V4: Shou2 
Table 12. Effect interaction effect between nitrogen fertilizer levels and Varieties on fresh weight per plant, dry leaves weight per plant, leaves fresh weigh yield, dry leaves yield and total leaves yield of stevia in 2016/2017 season.

\section{6/2017 Season}

\begin{tabular}{|c|c|c|c|c|c|c|c|c|c|c|c|c|c|}
\hline \multirow[t]{2}{*}{ treatmeant } & \multicolumn{3}{|c|}{ Leaves freshweigh/plant (g) } & \multicolumn{3}{|c|}{ dry leaves weight/plant (g) } & \multicolumn{3}{|c|}{$\begin{array}{l}\text { Leaves fresh yield ton cut/ } \\
\text { fed }\end{array}$} & \multicolumn{3}{|c|}{ Leaves yield ton cut / fed } & \multirow[t]{2}{*}{$\begin{array}{l}\text { Total leaves } \\
\text { yiedt/ fed/year }\end{array}$} \\
\hline & Cut1 & Cut2 & Cut3 & Cut1 & Cut2 & Cut3 & Cut1 & Cut2 & Cut3 & Cut1 & Cut2 & Cut3 & \\
\hline N1V1 & 140.8 & 29.0 & 61.4 & 40.67 & 8.50 & 12.03 & 4.230 & 0.873 & 1.84 & 2.077 & 0.541 & 0.453 & 2.701 \\
\hline N1V2 & 207.3 & 31.63 & 120.2 & 59.33 & 8.90 & 27.93 & 6.270 & 0.956 & 3.61 & 2.497 & 0.535 & 0.975 & 3.693 \\
\hline N1V3 & 97.4 & 16.33 & 46.83 & 27.63 & 4.80 & 12.0 & 2.487 & 0.488 & 1.77 & 0.831 & 0.299 & 0.407 & 1.351 \\
\hline N1V4 & 80.0 & 17.87 & 73.33 & 21.77 & 5.17 & 22.2 & 2.896 & 0.533 & 2.09 & 2.013 & 0.353 & 0.408 & 2.860 \\
\hline $\mathrm{N} 2 \mathrm{~V} 1$ & 193.1 & 35.33 & 111.2 & 58.03 & 10.07 & 31.13 & 5.803 & 1.057 & 3.34 & 2.324 & 0.781 & 1.053 & 3.735 \\
\hline $\mathrm{N} 2 \mathrm{~V} 2$ & 286.3 & 36.4 & 114.0 & 79.50 & 10.20 & 28.5 & 8.767 & 1.085 & 3.42 & 2.438 & 0.729 & 1.367 & 3.693 \\
\hline $\mathrm{N} 2 \mathrm{~V} 3$ & 118.3 & 22.67 & 80.4 & 34.57 & 6.03 & 21.6 & 3.367 & 0.677 & 2.15 & 1.104 & 0.569 & 0.480 & 1.351 \\
\hline N2V4 & 111.3 & 24.53 & 66.6 & 31.80 & 6.60 & 13.1 & 3.367 & 0.739 & 2.26 & 1.733 & 0.439 & 0.746 & 2.698 \\
\hline N3V1 & 288.1 & 48.73 & 144.6 & 83.33 & 14.10 & 32.4 & 8.670 & 1.473 & 4.35 & 3.085 & 0.949 & 1.170 & 4.716 \\
\hline N3V2 & 360.4 & 75.33 & 177.9 & 94.53 & 20.30 & 33.03 & 11.19 & 2.253 & 5.35 & 3.349 & 0.995 & 1.627 & 5.477 \\
\hline N3V3 & 184.3 & 32.33 & 88.0 & 53.03 & 9.00 & 22.33 & 5.290 & 0.970 & 2.75 & 1.578 & 0.671 & 0.747 & 2.552 \\
\hline N3V4 & 184.3 & 31.00 & 126.7 & 7.73 & 31.67 & 30.3 & 5.857 & 0.933 & 3.28 & 2.061 & 0.639 & 0.930 & 3.353 \\
\hline mean & 187.6 & 33.43 & 101. & 52.99 & 9.28 & 25.4 & 5.702 & 1.003 & 3.02 & 2.091 & 0.625 & 0.889 & 3.255 \\
\hline L s d 0.05 & 20.68 & 6.164 & 15.22 & 5.918 & 1.600 & 3.913 & 0.658 & 0.179 & 1.153 & 0.357 & 0.0695 & 0.248 & 0.4751 \\
\hline
\end{tabular}

N1: $20 \mathrm{~kg} \mathrm{~N}$ fed/cut.

V1: China $1 \quad$ V2: Egy1

N2: $30 \mathrm{~kg} \mathrm{~N}$ fed/cut

N3: $40 \mathrm{~kg} \mathrm{~N}$ fed/cut.

V3: Spanti

V4: Shou2 


\section{References}

Attia. A. E (2005) Effect of some agronomic treatments on stevia (stevia rebaudiana,bertoni) yield and quality in egypt. $\mathrm{Ph}$ D thesis.Fac of AgricAin shams Univ. Egypt.

Asmaa Haraz S, M (2016) Genetic improvement through selection of Stevia rebaudiana under Egyptian conditions. M.Sc.thesis, Fac of AgricSaba Basha . Alexandria Univ. Egypt.

Allam, A. I., Nassar, A. M. and Besheit, S. Y., 2001. nile.enal.sci.eg/ Arc Journal/uga.htm

Anami, E. T, J. P. Poletine, M. C. GonçalvesVidigal, P. S. V. Filho, G. F. Lacanallo, M. V. Kvitschal and A. Gonela (2010). Characterization and genetic divergence in Stevia rebaudiana(Bert.)Bertoni clones based in agronomical and morphological characteristics. Journal of Food, Agriculture \& Environment.8 (3\&4) : $463-469$.

Bartlett, M. S. (1937). Properties of sufficiency and statistical tests. Proceedings of the London. Series A-Math. Phys. Royal Society of Sci., 160(901): 268282.

Brandle, J.E. and N. Rosa (1992).Heritability for yield, leaf-stem ratio and stevioside content estimated from a landrace cultivar of Stevia rebaudiana. Candian Journal of Plant Science.72(4): 1263-1266.

Chalapathi, M. V., S.Thimmegowda, G. G. E.Rao, N. Devakumar and J.Chandraprakash (1999).Influence of fertilizer level on growth, yield and nutrient uptake of ratooncrop of stevia (Stevia rebaudiana). Journal of Medical and Aromatic Plant Science. 21 : 947-949.

Frederico, A.P., P.M. Ruas, M.A. Marinmorlaes, C.F. Ruas and J.N. Nakajima (1996).Chromosome studies in some Stevia (Compositae) species from southern Brazil. Brazilian Journal of Genetics.19 (4): 605-609

Madan, S., Ahmad, S., Singh, G.N., Kohli, K., Kumar, Y., Singh, R., and Garg, M. 2010. Stevia rebaudiana(Bert.)Bertoni - A Review. Indian Journal of Natural Products and Resources.1: 267-286.

Maheshwer .H.M. (2005) Effect of different levels of nitrogen and dates of planting on grwth and yield of stevia (Stevia rebaudiana Bert.) M.S Of Sci (Agri) .Unive of Agril Sci Dharwad

Metivier, J and A. M. Viana (1979). Determination of microgram quantities of stevioside(sweetening compound) from leaves of stevia rebaudiana by two-dimensional thin layer chromatography. Journal of Experimental Botany.30 (117): 805810.

Megeji, N.W., Kumar, J.K., Singh, V., Kaul, V.K., and Ahuja, P.S. 2005.Introducing Stevia rebaudiana, a natural zero-calorie sweetener.Current Science. 88: 801-804.

Metivier, J and A. M. Viana (1979). Determination of microgram quantities of stevioside(sweetening compound) from leaves of stevia rebaudiana by two-dimensional thin layer chromatography. Journal of Experimental Botany.30 (117): 805810

Nitu, S, M. Punit and Ch. Ad (2013).Genetic Variability for Morphological Characters and Glycosides in Stevia (Stevia rebaudianaBertoni).Indian Journal of Plant Genetic Resources. 26(3): 243-244.

Noshiyama, P., Alurrez, M. and Vieira, L. E. 1991.Determination of soluble sterioside and carbohydrates in leaves of Stevia rebaudiana by near infrared reflectance spectroscopy. Argentina Biol. Tech., 34: 361-74.

Payne, R. W., D. A. Murray, S. A. Harding, D. B. Baird and D. M. Soutar (2009). Gen Stat for Windows $\left(12^{\text {th }}\right.$ Edition $)$ Introduction. VSN International, Hempstead, UK.

Shizhen, S and W. Wanzhong (1988). The Variation of Stevia rebaudianaBertoni Quantity Character and Relations to The Yield. Journal ActaAgronomia.14(2): 167-173.

Savita, S. M., K. Sheela, A.G.S. SharanSunanda and P. Ramakrishna ( 2004). Stevia rebaudiana - A Functional Component for Food Industry.Journal of Human and Ecology. 15 (4): 261-264

Shock, C. C., 1982, Rebaudi'sstevia : Natural noncaloric sweetness. Cal. Agri., $36: 4-5$.

Singh, S.D., and Rao, G.P. 2005. Stevia: The herbal sugar of 21st century. Sugar Tech. 7: 17-24.

Soejarto D. (2002). Botany of Stevia and Stevia rebaudiana.In:Kinghorn A (Ed), Stevia: The genus Stevia. Taylor \& Francis, London, UK

Yadav, A.K., Singh, S., Dhyani, D., and Ahuja, P.S. 2011. A review on the improvement of stevia (Stevia rebaudiana(Bertoni)).Canadian Journal of Plant Science. 91(1): 1-27.

Zaidan, L.B.P., S.M.C. Dietrich and G.M. Felippe (1980).Effect of photoperiod on flowering and stevioside content in plants of Stevia rebaudianaBertoni. Japanase Journal of Crop Sci (49): 569-574 


\section{التقيم التباتي لبعض أصناف الاستيفيا تحت مستويات مختلفة من التسمي الازوتي \\ ابوبكر عبد الوهاب طنطاوي * احمد السيد عطية *** ناريمان نايف قناوي \\ *كلية الزراعة جامعة المنيا**مركز البحوث الزراعية - الجيزة}

اجريت الدراسة في محطة بحوث الجيزة مركز البحوث الزراعية موسمي 2015- 2016 و 2016-2017 لدراسة تاثير التسمبد النتروجينى (20) ، 30و 40 كجم نتروجين/ فدان / حشة ) وبعض الاصناف (shou 2. spantil china 1،Egy 1) وتفاعلهما علي الصفات تحت الدراسه في الموسمين. * اعطت معدلات التسميد الازوتي اختلافات عاليه المعنويه لجميع الصفات تحت الدراسة عند مستوي معنويه 5 \% اعطي معدل تسميد 40 كجم

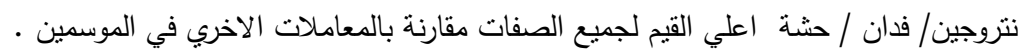

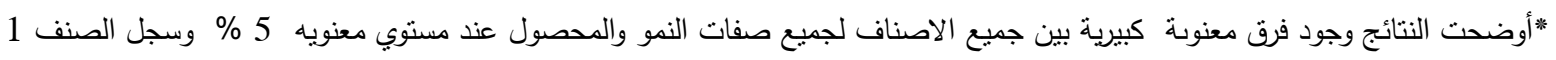
Egy *أوضحت النتائج أيضا ان التفاعل بين اضافة معدل كجم نتروجين للحشة والصنف Egy 1 اعلي القيم لجميع الصفات ماعد طول النبات وعدد الافرع في الموسمين . 